\title{
A STUDY ON IMPACT OF CROP LOAN TO THE AGRICULTURE DEVELOPMENT WITH SPECIAL TO REFRENCE CO-OPERATIVE AGRICULTURE AND RURAL DEVELOPMENT BANK
}

\author{
Narendra.K \\ Assistant Professor, Surana College, Bangalore \\ Maruteesh K \\ Student, M. Com., Surana College, Bangalore
}

\begin{abstract}
Primary co-operative agriculture and rural development bank is one of the cooperative banks which is established at the 1933.It gives important primarily for agriculture sector as well as mini agriculturists. It also plays more important in development of farmers and rural areas. The main head office is located in Bangalore, this bank will contain 177 branches in all over Karnataka.
\end{abstract}

Keywords: Crop Loan to the Agriculture Development.

Cite this Article: Narendra.K and Maruteesh K, A Study on Impact of Crop Loan to the Agriculture Development with Special to Refrence Co-Operative Agriculture and Rural Development Bank, International Journal of Advanced Research in Management, 10(1), 2018, pp. 8-33.

http://iaeme.com/Home/issue/IJARM?Volume=10\&Issue=1

\section{INTRODUCTION}

Primary co-operative agriculture and rural development bank is one of the co-operative banks which is established at the 1933.It gives important primarily for agriculture sector as well as mini agriculturists. It also plays more important in development of farmers and rural areas. The main head office is located in Bangalore, this bank will contain 177 branches in all over Karnataka.

The head office will provide financial facilities ton its sub -branches. This bank will have formed by shareholders. This bank having the main aim of development of agriculture and rural area development it provided the many facilities. The bank will give the finance for various activities like purchasing the tractor, agriculture equipment's, fisheries, coconut form, etc. 
A Study on Impact of Crop Loan to the Agriculture Development with Special to Refrence CoOperative Agriculture and Rural Development Bank

Promoter of a bank is shareholders, farmer's needs loans for the purchase of seeds, fertilizers, pesticides, feeds, marketing of agricultural products, livestock, repair of wells, payments of wages etc.

Interest rate as per RBI directives on interest rates issued from time to time for the purpose of valuation of the land for fixing the quantum of financial assistance, the price indicated by the farmers may be cross checked with the last 5 years average registration value available with the Registrar / Sub- Registrar of the area and view may be taken by the bank.

Quantum of loan it will depend on the area of the land to be purchased and its valuation and also development cost.

Repayment period loan may be repaid in 7-12 years (as against the earlier stipulation of 710 years) in half yearly /yearly instalments including a maximum moratorium period of 24 months. The moratorium period may be fixed taking into account the gestation period of the project and cash flow.

Increase in repayment period up to maximum of 12 years, will provide some relief to the small farmers towards repayment of loan.

NABARD would provide refinance to banks for the loans disbursed by them for purchase of land under the scheme broadly on the same terms and conditions as applicable to schematic finance. Agriculture credit clearly started to grow after bank nationalization, and it has been growing continuously since then. With all the concerns and skepticism expressed the difficult and continuous changes in institutional credit have indeed borne fruit. Over the years there has been a significant increase in the access of rural cultivation to institutional credit and, simultaneously,

The role of informal agencies, including money lenders, as source of credit has declined. According to all India Debt and Investment survey 1991-92. The relative shares of institutional agencies in the total cash debt of rural cultivators increased from $31.7 \%$ in 1971 to $63.2 \%$ in 1981 and further to $66.3 \%$ in 1991 . Nonetheless,

Recent years have again been characterized by a concern over the falling share of agricultural credit as a proportion of total credit. This is indeed true but is this the correct metric to look at the progress of agricultural credit? what would be more relevant is to evaluate agricultural, proportion of agricultural GDP or short-term credit has as a proportion of the value of inputs; or long-term credit as a proportion of private investment.

As might be expected, the share of agricultural value added has been falling as a share of total credit, to agriculture may also be expected to fall as a proportion of total credit, assuming relative stability in the share of purchased inputs as a proportion of value added. What is interesting is that the Share of agricultural credit as a proportion of agricultural GDP has been rising continuously since the 1950s, and even as a proportion of total GDP until the 1980s. There was indeed a fall in the mid-1990s but has again risen now. It is true, however, that agricultural credit has indeed fallen as a proportion of total credit.

It is quite remarkable how long it has taken to really substitute institutional credit for informal money lending channels and how tortuous the process of change has been, change of any significance took over 50 years from the beginning of serious attention in the 1930 s to the 1980s.

It was the nationalization of banks in 1969 and subsequent spread of rural bank branches that has really made a difference in reducing, finally the share of money lenders in agricultural credit.

Among the striking features of the agricultural credit scene in India are the wide regional disparities in the disbursement of agricultural credit by scheduled commercial banks (excluding RRBs). 
The correct way to evaluate the performance of agricultural credit is look at the ratio of agricultural credit to state agricultural value added. It is difficult to obtain these data. So, as a second best, we can look at agricultural credit as a proportion of net state domestic product(NSDP).

The Southern states stand out with a substantially higher share of agricultural credit followed by the Northern and central regions. Whereas the ratio for the southern region increased during the latter part of the 1990s, it remained stationery for the Northern, central and north-east regions.

It is also notable that the southern states have a much more active co-operative movement and hence their share of agricultural credits is likely to be even higher.

The low share of the western region is surprising but could be because of the very active role of co-operatives in this region. The east and north-eastern regions clearly get a very low share.

\section{OBJECTIVES OF PRIMARY CO-OPERATIVE AGRICULTURE AND RUARAL DEVELOPMENT BANK}

- Providing long-term and short-term loans to the agriculturists.

- Development of rural areas

- Providing finance to the mini agriculturists at reasonable interest rates to develop their agriculture activities.

- Providing various finance schemes at every year to different customers.

- Co-operates with various agriculturists and make to agriculture development

\subsection{The primary co-operative agriculture and rural development bank}

\subsubsection{Major lending loans to such as}

\subsubsection{AGRICULTURE}

Loans for crops.Loan for plantation of coconut trees,Loans for plantation for papaya ,Loan for plantation of grapes, Loan for plantation of agree cultural gropes ,Loan for coconut schemes,Loan for pomegranate schemes ,Loan for plantation of sapota ,Loan for plantation of medicine plants

\subsubsection{SERI CULTURE}

Purchase of agriculture land, Purchase of agriculture equipment's ,Purchase of tractor and tiller,Loans to plantation of grapes, Construction of well ,Pump set ,Drilling of borewell ,Yasaswini formers healthinsurance ,Animal insurance, Purchase of cattle's.

Agricultural credit needs can be classified into three categories as per Gowribidanur branch:

\subsubsection{Short term; ( for periods up to 15 months)}

Short term loans are required for the purchase of seeds, fertilizers, pesticides, feed marketing of agriculture produce, payment of wages of hired labour, litigation and variety of consumption and un productive purposes. The period of such loans is less than 15 months. Main agencies granting lans are moneylenders and co-operative societies. These are expected to be repaid after the harvest. 
A Study on Impact of Crop Loan to the Agriculture Development with Special to Refrence Co-

Operative Agriculture and Rural Development Bank

\subsubsection{Medium term :( from 15 months up to 5 years $)$}

Medium term loans are required for purchase of cattle, small agriculture implements, repairs and construction of wells etc. the periods of such loan extend from 15 months to 5 years. The loan is provided by moneylenders, relative of farmers, co-operative societies and commercial banks etc.

\subsubsection{Long term: (above 5 years)}

Long term loans are required for effecting permanent improvements of land, digging of tube wells, purchase of larger implements, machinery like tractors and repayment of old debts. The period of such loan extends beyond 5 years.

\section{PROBLEMS FACED BY FORMERS IN GOWRIBIDANUR BRANCH}

Rural development means nothing but the transformation of the subsistence agricultural production to a market oriented agricultural economy. Availability and access to financial resources is one of the key elements to his transition. Financial resource is a very important, if not the most important, factor in economic development.

Shortage of financial is one of the major problems facing small farmers. Farmers need financial resources to buy improved agricultural inputs and farm implements so that they can increase their output and income level and break the cycle of poverty.

Farmers investment in these technologies cannot be real without having place organizations and systems that are capable of adequately providing rural financial services to farmers. So, the effort to develop agriculture could suffering in the absence of strong.

Agriculture is unorganized profession. Its success and failure depend upon on climatic factors. It is also not possible to distinguish productive and unproductive loans required for farmers.

Therefore, banks do not show much interest in advancing loans to agriculture therefore farmers have to depend on moneylenders, Mahajan's etc. who exploits them due to strong grip on socio-economic position in rural areas.

\section{RESEARCH METHODOLOGY}

\subsection{Statement of Problems}

What are the banks have been playing in financing crop loans?

What is their contribution to agriculture development?

What are the merits and demerits of the present crop loan scheme?

What are the steps would be required to make the present scheme of crop loan efficiently?

\subsection{Objectives of the Study}

To find out impact of crop loan to the area of cultivation

To find out the impact of crop loan and expenditure

To find out the impact of crop loan and income per cultivation

To find out the impact of crop loan and assets beneficiary

To find out the impact of crop loan and the liabilities

\subsection{Scope of the study}

To understand the theoretical background of crop loan and agriculture. 
To identify the utilization of crop loan by the farmers.

To give valuable suggestions based on findings of the study.

\section{LITERATURE REVIEW}

VincelyJabakar. S (1997): -In his study entitled "Impact of institutional credit on agricultural development". A case study of Kanyakumari district concluded that co-operatives are the significant institutional agencies considering the other institutional agencies catering to the financial requirements of the farmers.

Bhai and Ganeshwar (1997) In this article "A study co-operatives crop loan overdues" the loan overdues of the crop loans, studying the pattern of the financing and recovery trends of cooperative crop loan in Orissa. In this article suggesting necessary policy measure to be pursed to reduce the amount of overdues loans that creates problem in the smooth of credit. The study pertains to the evaluation of the implementation and performance of the crop loan system under the co-operative sector in Myurbhaj. In the study excludes the performance of other participating financial institutions like, commercial Banks, Regional banks and Rural banks.

The study pertaining to the district of Mayarabhaj thus, under taken revels a series of relevant facts and promises to advance same valuable suggestions that could be applied to control down the levels of loans

Saraiya.S.G. (1998) In his study entitled "Rural banking in India" has traced the organizational structure of the banking institution in the rural sector which is not sound in regard to the existence of facility of the funds in primary credit societies' to lend money adequacy to agriculturists. The banking habit in the rural sector is also not well developed due to the poor functioning of co-operative banks and the officials of central co-operative banks are not well qualified and trained for the effective implementation of the suggestions.

Arutse and Zeaden (2000): -In their study entitled "Agricultural credit- A study in Villianur Block of Region", concluded that the repayment is regular for crop loans, since the farmers need the credit for the next season. Hence, the payment is regular and complete. But in the case of long-term loan, there are huge amounts outstanding. From the decision with the farmers, it was observed that they are not interested in repaying it. Because it will get cancelled at the time of election.

Amuthasurabi J, and Vasanth Kumar A (2001): -In their article entitled "Sustained Agricultural development" have stated that the policy formulations arise in a new way to achieve the formations of food security through sustainable agriculture and rural development coupled with environmental extension. They also stated that the country should have a compressive agricultural extension policy. They opined that present policy is not focusing much on the conservation of natural resources which are locally originating and it needs to refer the success stories of the pioneering countries with enabling policies to suitable concept.

Srivastava. B (2004): -In his Book "crop loan of Agriculture in India" pointed out that more than half of the crop loans and advances provided to farmers came from the co-operative Banks and co-operative Societies. He also pointed out that overdues were high in commercial banks the main causes being diversion of loans from productive purposes to unproductive purposes. Inadequate supervision, and unsatisfactory management, political, financial, and other considerations.

Nidhesh K.B (2009): -In his study "Role of co-operative Banks in to the credit needs of Ruralmases" has observed the role of primary co-operative banks in providing credit to rural poor and he suggested improving the performance of co-operative banks.

Iswarahas. C, Dhiagra (2010) In his study "The Indian economy environment and Policy" stated that debt payment was a must and a legal obligation. It should not be totally unrelated to 
A Study on Impact of Crop Loan to the Agriculture Development with Special to Refrence Co-

Operative Agriculture and Rural Development Bank

borrower's capacity. He has also stated that $40 \%$ of the gross value of the product production by the small farmers was utilized for their own consumption another $40 \%$ to meet their fresh commitments and also for repayment of the loans and another $20 \%$ utilized for the repayment of old debts.

Chandrashekar S, Manika S, and Soleman Raj D (2011) In their Study entitled "Role of agriculture in cultivator Generation" concluded that the borrowers farmed achieved a substantial rise in crop productivity. Improvement in irrigation facilities with the sustained use of fertilizers and other inputs were evidently the decisive forces. It was observed that bank loans have helped to raise per hectare income of the borrower farmed substantially".

Geetha. K (2012): -In her study "A study on impact of crop loan to the agriculture development" in this study has been undertaken mainly to help the government to the government to take up policy decisions and formulate suitable schemes and programs.

In the study on the impact of the agriculture loan on agriculture development by the Kanyakumari district with reference primary agriculture co-operative credit society. In this study on fund mobilization policies in primary agriculture co-operative credit societies'.

\subsection{Sample Design}

A sampling Design is the frame work, or road map, that serves as the basis for the selection of survey sample and affects many important aspects of a survey.

\subsection{Sample Size}

100 respondents sample size for the project that all the respondents is the borrowers of the Primary co-operative and agriculture development bank.

\subsection{Sampling Technique}

Non- probability convenient sampling.

Tools Used-

Tables

Graphs

Pair- t test

\subsection{Statistical Tool}

In this project paired t-test used for the find out impact of before and after crop loan borrowed.

\subsection{Hypothesis}

There is no significant difference between crop loan and area of cultivation.

There is no significant difference between crop loan and cultivated expenditure.

There is no significant difference between crop loan and income from crops.

There is no significant difference between crop loan and liabilities.

\subsection{Geographical Area Coverd}

Gowribidanur is a town or Taluk in kolar now chikkaballapur District in the south Indian state of Karnataka. It is about $75 \mathrm{~km}$ from Bangalore and $25 \mathrm{~km}$ chikkabalapur. Along with native language is kannada, the other languages of telugu and Urdu are spoken since the town borders the neighbouring State Andra Pradesh. 
Gowribidanur is at average elevation of 694 meters. As of census, gowribidanur had a population of 80,673 . Males constitute $51 \%$ of the population and females $49 \%$. Gowribidanur has an average literacy rate $72 \%$, male literacy is $77 \%$ and female is $67 \% .11 \%$ of the population is under 6 years age. The gowibidanur has 6 hoblies and 239 villages.

\subsubsection{Limitations of study}

The study was limited to only one bank Is Primary Co-operative Agriculture and rural Development Bank, Gowribidanur Branch.

The study limited to the respondents who have taken the loan from bank.

Financial limitation and selected few crops.

\section{SWOT ANALYSIS OF THE BANK}

\subsection{Strengths}

- The farmers are preference or Interested to take loans from these Bank.

- Attractive interest rates.

- Good services providing for customers.

- In lending competitive ability matches with other banks.

- In the India the primarily agriculture is back bone of the country the bank will provides lending for agriculture sectors.

\subsection{Weakness}

- Less promotional activities.

- Lack of skilled employees to deal with situations needing competence.

- Rigid working hours lending to overload of work.

- Low interest rates.

- Losses mounting since last 4 years.

- Old rules and regulations.

- Lack of funds to expand the business activities.

- Huge competition of other banks

- The bank is Using old systems and software's.

- Lack of efforts to recover the principle amount of loan from the customers.

- Lack of literacy among the customers of the bank.

- In last year the bank will facing losses.

\subsection{Opportunities}

- The important in efficiency of identifying the future risks

- Expands the core business

- Make profitability by new acquisitions

- Availability of large customers.

- Availability of land lord customers in Gowribidanur

- To attract the customers with the help of promotions. 
A Study on Impact of Crop Loan to the Agriculture Development with Special to Refrence CoOperative Agriculture and Rural Development Bank

\subsection{Threats}

- Changing in the government policies.

- Increasing the competitors.

- The bank is failure for the recovery of the loan amount from the customers.

- The farmers were selling the agriculture lands.

- Lack of rain falls caused the farmers to diversified the other business activities.

- Bank need to follow the majority shareholders decisions.

\section{DATA ANALYSIS AND INTERPRETATION}

\section{Hypothesis-A}

HO - THERE IS NO SIGNIFICANT DIFFRENCE BETWEEN CROP LOAN AND AREA OF CULTIVATION.

H1- THERE IS A SIGNIGNIFICANT DIFFRENCE BETWEEN CROP LOAN AND ARE OF CULTIVATION

\section{Crop Name - Paddy}

Paired Samples Statistics

\begin{tabular}{|l|c|c|c|c|c|}
\hline \multicolumn{2}{|c|}{} & Mean & N & Std. Deviation & $\begin{array}{c}\text { Std. Error } \\
\text { Mean }\end{array}$ \\
\hline \multirow{2}{*}{ Pair 1 } & BEFORE & 3.8824 & 17 & 2.41434 & .58556 \\
\cline { 2 - 6 } & AFTER & 4.7059 & 17 & 2.73895 & .66429 \\
\hline
\end{tabular}

Paired Samples Correlations

\begin{tabular}{|c|c|c|c|c|}
\hline \multicolumn{2}{|c|}{} & N & Correlation & Sig. \\
\hline Pair 1 & $\begin{array}{c}\text { BEFORE \& } \\
\text { AFTER }\end{array}$ & 17 & .902 & .000 \\
\hline
\end{tabular}

Paired Samples Test

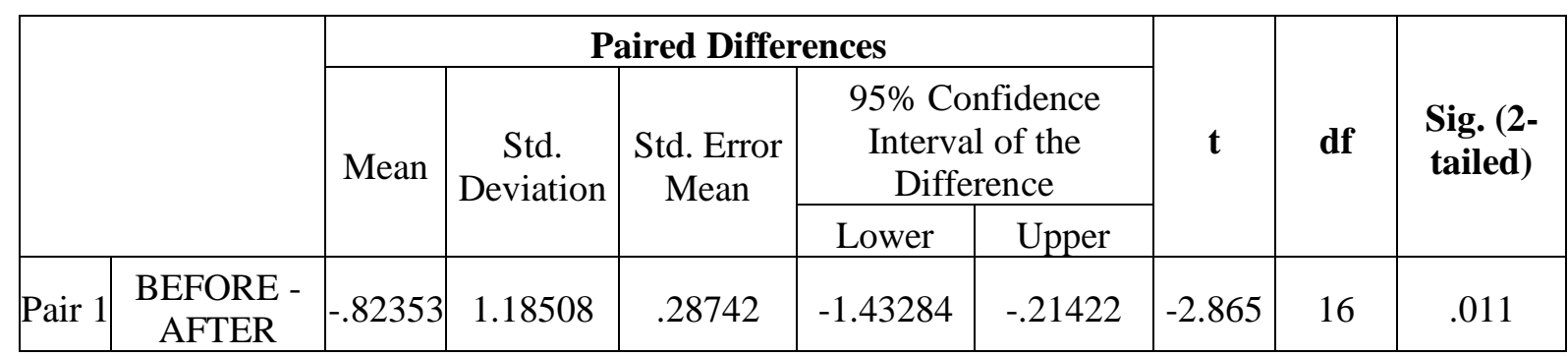

\section{DATA ANALYSIS AND INTERPRETATION}

In this above table the P value is less than 0.05 , so that the Null Hypthises(H0) is Rejected and Alternative hypothesis(H1) is Accepted.

THERE IS A SIGNIFICANT DIFFERENCE BETWEEN CROP LOAN AND AREA OF CULTIVATION. 


\section{Hypothesis-A}

H0 - THERE IS NO SIGNIFICANT DIFFRENCE BETWEEN CROP LOAN AND AREA OF CROP CULTIVATION

H1- THERE IS A SIGNIFICANT DIFFERENCE BETWEEN CROP LOAN AND AREA OF CROP CULTIVATION

\section{Crop Name- Banana}

Paired Samples Statistics

\begin{tabular}{|c|c|c|c|c|c|}
\hline \multicolumn{2}{|c|}{} & Mean & N & Std. Deviation & Std. Error Mean \\
\hline \multirow{2}{*}{ Pair 1 } & BEFORE & 3.6111 & 9 & 2.05818 & .68606 \\
\cline { 2 - 6 } & AFTER & 4.7222 & 9 & 1.71594 & .57198 \\
\hline
\end{tabular}

Paired Samples Correlations

\begin{tabular}{|c|c|c|c|c|}
\hline \multicolumn{2}{|c|}{} & N & Correlation & Sig. \\
\hline Pair 1 & $\begin{array}{c}\text { BEFORE \& } \\
\text { AFTER }\end{array}$ & 9 & .426 & .253 \\
\hline
\end{tabular}

Paired Samples Test

\begin{tabular}{|c|c|c|c|c|c|c|c|c|c|}
\hline & \multicolumn{5}{|c|}{ Paired Differences } & \multirow{3}{*}{$\mathbf{t}$} & \multirow{3}{*}{ df } & \multirow{3}{*}{$\begin{array}{l}\text { Sig. (2- } \\
\text { tailed) }\end{array}$} \\
\hline & & \multirow[t]{2}{*}{ Mean } & \multirow[t]{2}{*}{$\begin{array}{c}\text { Std. } \\
\text { Deviation }\end{array}$} & \multirow[t]{2}{*}{$\begin{array}{l}\text { Std. Error } \\
\text { Mean }\end{array}$} & \multicolumn{2}{|c|}{$\begin{array}{c}\text { 95\% Confidence } \\
\text { Interval of the } \\
\text { Difference }\end{array}$} & & & \\
\hline & & & & & Lower & Upper & & & \\
\hline Pair 1 & $\begin{array}{c}\text { BEFORE - } \\
\text { AFTER }\end{array}$ & $\begin{array}{c}- \\
1.11111\end{array}$ & 2.04294 & .68098 & -2.68146 & .45923 & -1.632 & 8 & .041 \\
\hline
\end{tabular}

\section{ANALYSIS AND INTERPRETATION-}

In this above table the $\mathrm{P}$ value is less than 0.05 so that the Null Hypothesis (H0) is Rejected and alternative Hypotheis (H1) is accepted.

\section{THERE IS A SIGNIFICANT DIFFRENCE BETWEEN CROP LOAN AND} AREA OF CULTIVATION.

\section{HYPOTHESIS-A}

HO- THERE IS NO SIGNIFICANT DIFFRENCE BETWEEN CROP LOAN AND AREA OF CULTIVATION

H1- THERE IS A SIGNIFICANT DIFFERENCE BETWEEN CROP LOAN AND AREA OF CULIVATION

\section{CROP NAME- TOMATO}

Paired Samples Statistics

\begin{tabular}{|c|c|c|c|c|c|}
\hline \multicolumn{2}{|c|}{} & Mean & N & Std. Deviation & $\begin{array}{c}\text { Std. Error } \\
\text { Mean }\end{array}$ \\
\hline \multirow{2}{*}{ Pair 1 } & BEFORE & 4.5909 & 11 & 2.92248 & .88116 \\
\cline { 2 - 6 } & AFTER & 4.2727 & 11 & 3.10937 & .93751 \\
\hline
\end{tabular}


A Study on Impact of Crop Loan to the Agriculture Development with Special to Refrence CoOperative Agriculture and Rural Development Bank

Paired Samples Correlations

\begin{tabular}{|c|c|c|c|c|}
\hline \multicolumn{2}{|c|}{} & $\mathbf{N}$ & Correlation & Sig. \\
\hline Pair 1 & $\begin{array}{c}\text { BEFORE \& } \\
\text { AFTER }\end{array}$ & 11 & .866 & .001 \\
\hline
\end{tabular}

Paired Samples Test

\begin{tabular}{|c|c|c|c|c|c|c|c|c|c|}
\hline & \multicolumn{5}{|c|}{ Paired Differences } & \multirow{3}{*}{$\mathbf{t}$} & \multirow{3}{*}{ df } & \multirow{3}{*}{$\begin{array}{l}\text { Sig. (2- } \\
\text { tailed) }\end{array}$} \\
\hline & & \multirow[t]{2}{*}{ Mean } & \multirow[t]{2}{*}{$\begin{array}{c}\text { Std. } \\
\text { Deviation }\end{array}$} & \multirow[t]{2}{*}{$\begin{array}{l}\text { Std. Error } \\
\text { Mean }\end{array}$} & \multicolumn{2}{|c|}{$\begin{array}{l}\text { 95\% Confidence } \\
\text { Interval of the } \\
\text { Difference }\end{array}$} & & & \\
\hline & & & & & Lower & Upper & & & \\
\hline Pair 1 & $\begin{array}{c}\text { BEFORE - } \\
\text { AFTER }\end{array}$ & .31818 & 1.56960 & .47325 & -.73629 & 1.37265 & .672 & 10 & .517 \\
\hline
\end{tabular}

\section{ANALYSIS AND INTERPRETATION-}

In the above Table the P value is Greater than 0.05, so the Null Hypothesis is Accepted. (H0).

THERE IS NO SIGNIFICANT DIFFERENCE BETWEEN CROP LOAN AND AREA OF CROP CULTIVATION

\section{HYPOTHESIS-A}

HO - THERE IS NO SIGNIFICANT DIFFERENCE BETWEEN CROP LOAN AND AREA OF CROP CULTIVATION

H1- THERE IS A SIGNIFICANT DIFFERENT BETWEEN CROP LOAN AND AREA OF CULTIVATION

\section{CROP NAME- RAGI}

Paired Samples Statistics

\begin{tabular}{|c|c|c|c|c|c|}
\hline \multicolumn{2}{|c|}{} & Mean & N & Std. Deviation & $\begin{array}{c}\text { Std. Error } \\
\text { Mean }\end{array}$ \\
\hline \multirow{2}{*}{ Pair 1 } & BEFORE & 5.3000 & 30 & 3.53456 & .64532 \\
\cline { 2 - 6 } & AFTER & 5.3000 & 30 & 3.47305 & .63409 \\
\hline
\end{tabular}

Paired Samples Correlations

\begin{tabular}{|c|c|c|c|c|}
\hline \multicolumn{2}{|c|}{} & N & Correlation & Sig. \\
\hline $\mathrm{b}$ & $\begin{array}{c}\text { BEFORE \& } \\
\text { AFTER }\end{array}$ & 30 & .839 & .000 \\
\hline
\end{tabular}

Paired Samples Test

\begin{tabular}{|c|c|c|c|c|c|c|c|c|c|}
\hline & \multicolumn{5}{|c|}{ Paired Differences } & \multirow{3}{*}{$\mathbf{t}$} & \multirow{3}{*}{ df } & \multirow{3}{*}{$\begin{array}{l}\text { Sig. (2- } \\
\text { tailed) }\end{array}$} \\
\hline & & \multirow[t]{2}{*}{ Mean } & \multirow[t]{2}{*}{$\begin{array}{c}\text { Std. } \\
\text { Deviation }\end{array}$} & \multirow[t]{2}{*}{$\begin{array}{l}\text { Std. Error } \\
\text { Mean }\end{array}$} & \multicolumn{2}{|c|}{$\begin{array}{l}95 \% \text { Confidence } \\
\text { Interval of the } \\
\text { Difference }\end{array}$} & & & \\
\hline & & & & & Lower & Upper & & & \\
\hline Pair 1 & $\begin{array}{c}\text { BEFORE - } \\
\text { AFTER }\end{array}$ & .00000 & 1.98703 & .36278 & -.74197 & .74197 & .000 & 29 & 0.01 \\
\hline
\end{tabular}


ANALYISIS AND INTERPRETATION-

In this above table the $\mathrm{P}$ value is less than 0.05 , so the $\mathrm{H} 1$ - alternative hypothesis is accepted.

THERE IS A SIGNIFICANT DIFFRENCE BETWEEN CROP LOAN AND AREA OF CROP CULTIVATION

\section{HYPOTHESIS-A}

H0- THERE IS NO SIGNIFICANT DIFFERENCE BETWEEN CROP LOAN AND AREA OF CULTIVATION

H1-THERE IS A SIGNIFICANT DIFFERENCE BETWEEN CROP LOAN AND AREA OF CULTIVATION

\section{CROP NAME - CRON}

Paired Samples Statistics

\begin{tabular}{|c|c|c|c|c|c|}
\hline \multicolumn{2}{|c|}{} & Mean & N & Std. Deviation & $\begin{array}{c}\text { Std. Error } \\
\text { Mean }\end{array}$ \\
\hline \multirow{2}{*}{ Pair 1 } & BEFORE & 6.0303 & 33 & 4.09447 & .71276 \\
\cline { 2 - 6 } & AFTER & 5.8333 & 33 & 4.13572 & .71994 \\
\hline
\end{tabular}

Paired Samples Correlations

\begin{tabular}{|c|c|c|c|c|}
\hline \multicolumn{2}{|c|}{} & N & Correlation & Sig. \\
\hline Pair 1 & $\begin{array}{c}\text { BEFORE \& } \\
\text { AFTER }\end{array}$ & 33 & .905 & .000 \\
\hline
\end{tabular}

Paired Samples Test

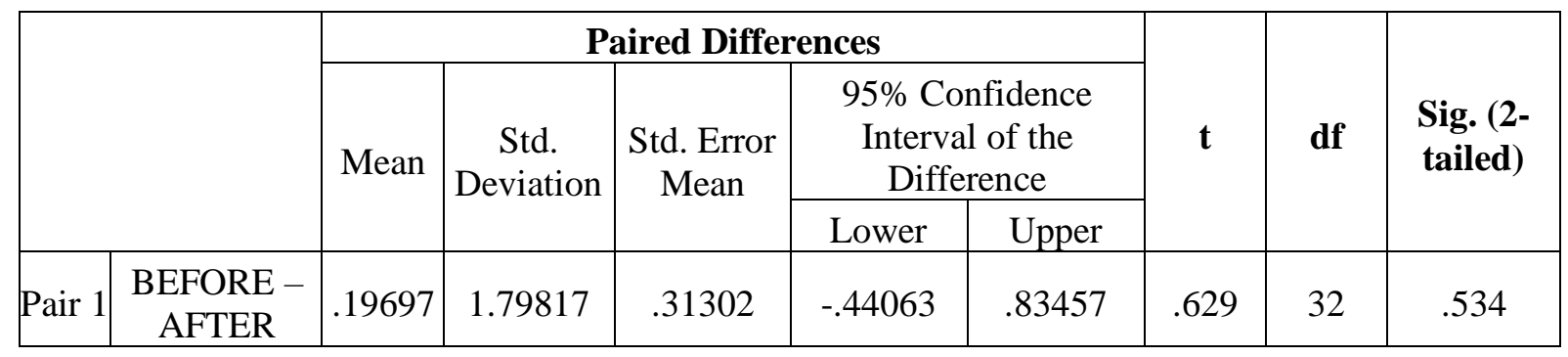

\section{ANALYSIS AND INTERPRETATION-}

In the above table the $\mathrm{P}$ value is greater than 0.05 , so the Null Hypothesis(H0) is accepted.

\section{THERE IS NO SIGNIFICANT DIFFERENT BETWEEN CROP LOAN AND} AREA OF CROP CULTIVATED.

\section{HYPOTHESIS-B}

H0-THERE IS NO SIGNIFICANT DIFFERNCE BETWEEN CROP LOAN AND EXPENDITURE PER CULTIVATION

H1-THERE IS A SIGNIFICANT DIFFERENCE BETWEEN CROP LOAN AND EXPENDITURE PER CULTIVATION. 
A Study on Impact of Crop Loan to the Agriculture Development with Special to Refrence CoOperative Agriculture and Rural Development Bank

\section{CROP NAME- PADDY}

Paired Samples Statistics

\begin{tabular}{|c|c|c|c|c|c|}
\hline \multicolumn{2}{|c|}{} & Mean & N & Std. Deviation & $\begin{array}{c}\text { Std. Error } \\
\text { Mean }\end{array}$ \\
\hline \multirow{2}{*}{ Pair 1 1 } & BEFORE & 12882.3529 & 17 & 5266.43087 & 1277.29710 \\
\cline { 2 - 6 } & AFTER & 14588.2353 & 17 & 5723.40396 & 1388.12936 \\
\hline
\end{tabular}

Paired Samples Correlations

\begin{tabular}{|c|c|c|c|c|}
\hline \multicolumn{2}{|c|}{} & N & Correlation & Sig. \\
\hline Pair 1 & $\begin{array}{c}\text { BEFORE \& } \\
\text { AFTER }\end{array}$ & 17 & .527 & .030 \\
\hline
\end{tabular}

Paired Samples Test

\begin{tabular}{|c|c|c|c|c|c|c|c|c|c|}
\hline & \multicolumn{5}{|c|}{ Paired Differences } & \multirow{3}{*}{$\mathbf{t}$} & \multirow{3}{*}{ df } & \multirow{3}{*}{$\begin{array}{l}\text { Sig. (2- } \\
\text { tailed) }\end{array}$} \\
\hline & & \multirow[t]{2}{*}{ Mean } & \multirow[t]{2}{*}{$\begin{array}{c}\text { Std. } \\
\text { Deviation }\end{array}$} & \multirow[t]{2}{*}{$\begin{array}{c}\text { Std. Error } \\
\text { Mean }\end{array}$} & \multicolumn{2}{|c|}{$\begin{array}{l}\text { 95\% Confidence } \\
\text { Interval of the } \\
\text { Difference }\end{array}$} & & & \\
\hline & & & & & Lower & Upper & & & \\
\hline $\begin{array}{c}\text { Pair } \\
1\end{array}$ & $\begin{array}{l}\text { BEFORE - } \\
\text { AFTER }\end{array}$ & $\begin{array}{c}- \\
1705.882 \\
35\end{array}$ & $\begin{array}{c}5359.1592 \\
8\end{array}$ & $\begin{array}{c}1299.7870 \\
5\end{array}$ & $\begin{array}{c}- \\
4461.3078 \\
0\end{array}$ & $\begin{array}{c}1049.5431 \\
0\end{array}$ & -1.312 & 16 & .008 \\
\hline
\end{tabular}

\section{ANALYSIS AND INTERPRETATION}

In the above table the $\mathrm{P}$ Value is less than the 0.05 , so that the Alternative hypothesis $(\mathrm{H} 1)$ is accepted.

\section{THERE IS A SIGNIFICANT DIFFENRENCE BETWEEN CROP LOAN AND EXPENDITURE PER CULTIVATION}

\section{HYPOTHESIS -B}

HO- THERE IS NO SIGNIFICANT DIFFERENCE BETWEEN CROP LOAN AND EXPENDITURE PER CULTIVATION

H1-THERE IS A SIGNIFICANT DIFFERENCE BETWEEN CROP LOAN AND EXPENDITURE PER CULTIVATION

\section{CROP NAME- BANANA}

Paired Samples Statistics

\begin{tabular}{|c|c|c|c|c|c|}
\hline \multicolumn{2}{|c|}{} & Mean & N & Std. Deviation & $\begin{array}{c}\text { Std. Error } \\
\text { Mean }\end{array}$ \\
\hline \multirow{2}{*}{ Pair 1 } & BEFORE & 15777.7778 & 9 & 3562.92639 & 1187.64213 \\
\cline { 2 - 6 } & AFTER & 17111.1111 & 9 & 4891.17686 & 1630.39229 \\
\hline
\end{tabular}


Narendra.K and Maruteesh K

Paired Samples Correlations

\begin{tabular}{|l|c|c|c|c|}
\hline \multicolumn{2}{|l|}{} & N & Correlation & Sig. \\
\hline Pair 1 & BEFORE \& AFTER & 9 & .393 & .296 \\
\hline
\end{tabular}

Paired Samples Test

\begin{tabular}{|c|c|c|c|c|c|c|c|c|c|}
\hline & \multicolumn{5}{|c|}{ Paired Differences } & \multirow{3}{*}{$\mathbf{t}$} & \multirow{3}{*}{ df } & \multirow{3}{*}{$\begin{array}{l}\text { Sig. (2- } \\
\text { tailed) }\end{array}$} \\
\hline & & \multirow[t]{2}{*}{ Mean } & \multirow[t]{2}{*}{$\begin{array}{c}\text { Std. } \\
\text { Deviation }\end{array}$} & \multirow[t]{2}{*}{$\begin{array}{l}\text { Std. Error } \\
\text { Mean }\end{array}$} & \multicolumn{2}{|c|}{$\begin{array}{l}95 \% \text { Confidence } \\
\text { Interval of the } \\
\text { Difference }\end{array}$} & & & \\
\hline & & & & & Lower & Upper & & & \\
\hline Pair 1 & $\begin{array}{l}\text { BEFORE - } \\
\text { AFTER }\end{array}$ & $\begin{array}{c}- \\
1333.3333 \\
3\end{array}$ & 4789.31102 & 1596.43701 & 5014.72367 & 2348.05700 & -.835 & 8 & .028 \\
\hline
\end{tabular}

\section{ANALYSIS AND INTERPRETATION-}

In this test the $\mathrm{P}$ value is less than 0.05 The alternative hypothesis is accepted.

\section{CONCLUSSION-}

THERE IS A SIGNIFICANT DIFFERENCE BETWEEN CROP LOAN AND EXPENDITURE PER CULTIVATION.

\section{HYPOTHESIS-B}

H0-THERE IS NO SIGNIFICANT DIFFERENCE BETWEEN CROP LOAN AND EXPENDITURE PER CULTIVATION

H1-THERE IS A SIGNIFICANT DIFFERENCE BETWEEN CROP LOAN AND EXPENDITURE PER CULTIVATION

\section{CROP NAME- TOMATO}

Paired Samples Statistics

\begin{tabular}{|l|l|l|l|l|l|}
\hline \multicolumn{2}{|c|}{} & Mean & N & Std. Deviation & $\begin{array}{l}\text { Std. Error } \\
\text { Mean }\end{array}$ \\
\hline \multirow{2}{*}{ Pair 1 } & BEFORE & 12545.4545 & 11 & 4719.39904 & 1422.95235 \\
\cline { 2 - 6 } & AFTER & 13363.6364 & 11 & 6313.04566 & 1903.45488 \\
\hline
\end{tabular}

Paired Samples Correlations

\begin{tabular}{|l|l|l|l|l|}
\hline \multicolumn{2}{|l|}{} & N & Correlation & Sig. \\
\hline Pair 1 & $\begin{array}{l}\text { BEFORE \& } \\
\text { AFTER }\end{array}$ & 11 & .775 & .005 \\
\hline
\end{tabular}

Paired Samples Test

\begin{tabular}{|c|c|c|c|c|c|c|c|c|c|}
\hline & & \multicolumn{5}{|c|}{ Paired Differences } & \multirow{3}{*}{$\mathbf{t}$} & \multirow{3}{*}{ df } & \multirow{3}{*}{$\begin{array}{l}\text { Sig. (2- } \\
\text { tailed) }\end{array}$} \\
\hline & & \multirow{2}{*}{ Mean } & \multirow{2}{*}{$\begin{array}{c}\text { Std. } \\
\text { Deviation }\end{array}$} & \multirow{2}{*}{$\begin{array}{l}\text { Std. Error } \\
\text { Mean }\end{array}$} & \multicolumn{2}{|c|}{$\begin{array}{l}\text { 95\% Confidence Interval } \\
\text { of the Difference }\end{array}$} & & & \\
\hline & & & & & \begin{tabular}{|l|} 
Lower \\
\end{tabular} & Upper & & & \\
\hline Pair 1 & $\begin{array}{c}\text { BEFORE - } \\
\text { AFTER }\end{array}$ & $\mid \begin{array}{c}- \\
818.18182\end{array}$ & 3995.45196 & 1204.67409 & -3502.36297 & 1865.99933 & -.679 & 10 & .512 \\
\hline
\end{tabular}


A Study on Impact of Crop Loan to the Agriculture Development with Special to Refrence Co-

Operative Agriculture and Rural Development Bank

\section{ANALYSIS AND INTERPRETATION-}

In the above table the $\mathrm{P}$ value is greater than 0.05 so that the Null Hypothesis is accepted.

\section{CONCLUSION-}

THERE IS NO SIGNIFICANT DIFFERENCE BETWEEN CROP LOAN AND EXPENDITURE PER CULTIVATION.

\section{HYPOTHESIS-B}

HO- THERE IS NO SIGNIFICANT DIFERENCE BETWEEN CROP LOAN AND EXPENDITURE PER CULTIVATION

H1- THERE IS A SIGNIFICANT DIFFERENCE BETWEEN CROP LOAN AND EXPENDITURE PER CUTIVATION.

\section{CROP NAME- RAGI}

Paired Samples Statistics

\begin{tabular}{|c|c|c|c|c|c|}
\hline \multicolumn{2}{|c|}{} & Mean & N & Std. Deviation & $\begin{array}{c}\text { Std. Error } \\
\text { Mean }\end{array}$ \\
\hline \multirow{2}{*}{ Pair 1 } & BEFORE & 15783.3333 & 30 & 3951.61105 & 721.46217 \\
\cline { 2 - 6 } & AFTER & 15083.3333 & 30 & 3959.02142 & 722.81511 \\
\hline
\end{tabular}

Paired Samples Correlations

\begin{tabular}{|c|c|c|c|c|}
\hline \multicolumn{2}{|c|}{} & N & Correlation & Sig. \\
\hline Pair 1 & $\begin{array}{c}\text { BEFORE \& } \\
\text { AFTER }\end{array}$ & 30 & .868 & .000 \\
\hline
\end{tabular}

Paired Samples Test

\begin{tabular}{|c|c|c|c|c|c|c|c|c|c|}
\hline & \multicolumn{5}{|c|}{ Paired Differences } & \multirow{3}{*}{$\mathbf{t}$} & \multirow{3}{*}{ df } & \multirow{3}{*}{$\begin{array}{l}\text { Sig. (2- } \\
\text { tailed) }\end{array}$} \\
\hline & & \multirow[t]{2}{*}{ Mean } & \multirow[t]{2}{*}{$\begin{array}{c}\text { Std. } \\
\text { Deviation }\end{array}$} & \multirow[t]{2}{*}{$\begin{array}{l}\text { Std. Error } \\
\text { Mean }\end{array}$} & \multicolumn{2}{|c|}{$\begin{array}{l}95 \% \text { Confidence } \\
\text { Interval of the } \\
\text { Difference }\end{array}$} & & & \\
\hline & & & & & Lower & Upper & & & \\
\hline Pair 1 & $\begin{array}{c}\text { BEFORE - } \\
\text { AFTER }\end{array}$ & $\begin{array}{c}700.000 \\
00\end{array}$ & $\begin{array}{c}2032.4946 \\
5\end{array}$ & 371.08106 & -58.94597 & $\begin{array}{c}1458.9459 \\
7\end{array}$ & 1.886 & 29 & .069 \\
\hline
\end{tabular}

\section{ANALYSIS AND INTERPRETATION}

The above table the $\mathrm{P}$ value is than 0.05 is that the Null Hypoythesis is accepted.THERE IS NO SIGNIFICANT DIFFERNCE BETWEEN CROP LOAN AND EXPENDITURE PER CULTIVATION

\section{HYPOTHESIS-B}

HO- THERE IS NO SIGNIFICANT DIFFERENCE BETWEEN CROP LOAN AND EXPENDITURE PER CULTIVATION

H1- THERE IS A SIGNIFICANT DIEERENCE BETWEEN CROP LOAN AND EXPENDITURE PER CULTIVATION 
CROP NAME- CRON

Paired Samples Statistics

\begin{tabular}{|c|c|c|c|c|c|}
\hline \multicolumn{2}{|c|}{} & Mean & N & Std. Deviation & $\begin{array}{c}\text { Std. Error } \\
\text { Mean }\end{array}$ \\
\hline \multirow{2}{*}{ Pair 1 } & BEFORE & 16015.1515 & 33 & 4054.48218 & 705.79475 \\
\cline { 2 - 6 } & AFTER & 15512.1212 & 33 & 3920.04126 & 682.39159 \\
\hline
\end{tabular}

Paired Samples Correlations

\begin{tabular}{|c|c|c|c|c|}
\hline \multicolumn{2}{|c|}{} & N & Correlation & Sig. \\
\hline Pair 1 & $\begin{array}{c}\text { BEFORE \& } \\
\text { AFTER }\end{array}$ & 33 & .814 & .000 \\
\hline
\end{tabular}

Paired Samples Test

\begin{tabular}{|c|c|c|c|c|c|c|c|c|c|}
\hline & \multicolumn{5}{|c|}{ Paired Differences } & \multirow{3}{*}{$\mathbf{t}$} & \multirow{3}{*}{ df } & \multirow{3}{*}{$\begin{array}{l}\text { Sig. (2- } \\
\text { tailed) }\end{array}$} \\
\hline & & \multirow[t]{2}{*}{ Mean } & \multirow[t]{2}{*}{$\begin{array}{c}\text { Std. } \\
\text { Deviation }\end{array}$} & \multirow[t]{2}{*}{$\begin{array}{l}\text { Std. Error } \\
\text { Mean }\end{array}$} & \multicolumn{2}{|c|}{$\begin{array}{l}\text { 95\% Confidence } \\
\text { Interval of the } \\
\text { Difference }\end{array}$} & & & \\
\hline & & & & & Lower & Upper & & & \\
\hline Pair 1 & $\begin{array}{l}\text { BEFORE - } \\
\text { AFTER }\end{array}$ & $\begin{array}{c}503.0303 \\
0\end{array}$ & $\begin{array}{c}2438.0428 \\
7\end{array}$ & 424.40879 & -361.46211 & 1367.52271 & 1.185 & 32 & .045 \\
\hline
\end{tabular}

\section{ANALYSIS AND INTERPRETATION-}

The above table the P value is less than 0.05 so, that the Alternative Hypothesis (H1) is Accept.

THERE IS A SIGNIFICANT DIFFRENCE BETWEEN CROP LOAN AND EXPENDITURE PER CULTIVATION

\section{HYPOTHESIS-C}

H0-THERE IS NO SIGNIFICANT DIFFRENCE BETWEEN CROP LOAN AND INCOME PER CULTIVATION

H1- THERE IS A SIGNIFICANT DIFFRENCE BETWEEN CROP LOAN AND INCOME PER CULTIVATION

\section{CROP NAME - PADDY}

Paired Samples Statistics

\begin{tabular}{|c|c|c|c|c|c|}
\hline \multicolumn{2}{|c|}{} & Mean & N & Std. Deviation & $\begin{array}{c}\text { Std. Error } \\
\text { Mean }\end{array}$ \\
\hline \multirow{2}{*}{ Pair 1 } & BEFORE & 15782.3529 & 17 & 2882.92067 & 699.21097 \\
\cline { 2 - 6 } & AFTER & 15305.8824 & 17 & 2590.23903 & 628.22524 \\
\hline
\end{tabular}

Paired Samples Correlations

\begin{tabular}{|c|c|c|c|c|}
\hline \multicolumn{2}{|c|}{} & N & Correlation & Sig. \\
\hline Pair 1 & $\begin{array}{c}\text { BEFORE \& } \\
\text { AFTER }\end{array}$ & 17 & .590 & .013 \\
\hline
\end{tabular}


Paired Samples Test

\begin{tabular}{|c|c|c|c|c|c|c|c|c|c|}
\hline & \multicolumn{5}{|c|}{ Paired Differences } & \multirow{3}{*}{$\mathbf{t}$} & \multirow{3}{*}{ df } & \multirow{3}{*}{$\begin{array}{l}\text { Sig. (2- } \\
\text { tailed) }\end{array}$} \\
\hline & & \multirow[t]{2}{*}{ Mean } & \multirow[t]{2}{*}{$\begin{array}{c}\text { Std. } \\
\text { Deviation }\end{array}$} & \multirow[t]{2}{*}{$\begin{array}{l}\text { Std. Error } \\
\text { Mean }\end{array}$} & \multicolumn{2}{|c|}{$\begin{array}{l}95 \% \text { Confidence } \\
\text { Interval of the } \\
\text { Difference }\end{array}$} & & & \\
\hline & & & & & Lower & Upper & & & \\
\hline Pair 1 & $\begin{array}{c}\text { BEFORE - } \\
\text { AFTER }\end{array}$ & $\begin{array}{c}476.470 \\
59\end{array}$ & $\begin{array}{c}2492.3080 \\
2\end{array}$ & 604.47348 & -804.95595 & $\begin{array}{c}1757.8971 \\
3\end{array}$ & .788 & 16 & .042 \\
\hline
\end{tabular}

\section{ANALYSIS AND INTERPRETATION-}

In the above table the $\mathrm{p}$ value is less than the 0.05 , so that the Alternative hypothesis $(\mathrm{H} 0)$ is accepted.

\section{THERE IS A SIGNIFICANT DIFFRENCE BETWEEN CROP LOAN AND INCOME PER CULTIVATION}

\section{HYPOTHESIS-C}

HO- THERE IS NO SIGNIFICANT DIFFERENCE BETWEEN CROP LOAN AND INCOME PER CULTIVATION

H1-THRE IS A SIGNIFICANT DIFFERENCE BETWEEN CROP LOAN AND INCOME PER CULTIVATION

\section{CROP NAME- BANANA}

Paired Samples Statistics

\begin{tabular}{|c|c|c|c|c|c|}
\hline \multicolumn{2}{|c|}{} & Mean & N & Std. Deviation & $\begin{array}{c}\text { Std. Error } \\
\text { Mean }\end{array}$ \\
\hline \multirow{2}{*}{ Pair 1 1 } & BEFORE & 18102.7778 & 9 & 5179.89570 & 1726.63190 \\
\cline { 2 - 6 } & AFTER & 17944.4444 & 9 & 3506.81875 & 1168.93958 \\
\hline
\end{tabular}

Paired Samples Correlations

\begin{tabular}{|c|c|c|c|c|}
\hline \multicolumn{2}{|c|}{} & N & Correlation & Sig. \\
\hline Pair 1 & $\begin{array}{c}\text { BEFORE \& } \\
\text { AFTER }\end{array}$ & 9 & .922 & .000 \\
\hline
\end{tabular}

Paired Samples Test

\begin{tabular}{|c|c|c|c|c|c|c|c|c|c|}
\hline & \multicolumn{5}{|c|}{ Paired Differences } & \multirow{3}{*}{$\mathbf{t}$} & \multirow{3}{*}{ df } & \multirow{3}{*}{$\begin{array}{l}\text { Sig. (2- } \\
\text { tailed) }\end{array}$} \\
\hline & & \multirow[t]{2}{*}{ Mean } & \multirow[t]{2}{*}{$\begin{array}{c}\text { Std. } \\
\text { Deviation }\end{array}$} & \multirow[t]{2}{*}{$\begin{array}{l}\text { Std. Error } \\
\text { Mean }\end{array}$} & \multicolumn{2}{|c|}{$\begin{array}{c}95 \% \text { Confidence } \\
\text { Interval of the } \\
\text { Difference }\end{array}$} & & & \\
\hline & & & & & Lower & Upper & & & \\
\hline Pair 1 & $\begin{array}{c}\text { BEFORE - } \\
\text { AFTER }\end{array}$ & $\begin{array}{c}158.3333 \\
3\end{array}$ & $\begin{array}{c}2373.0255 \\
0\end{array}$ & 791.00850 & $\begin{array}{c}- \\
1665.73553 \\
\end{array}$ & 1982.40220 & .200 & 8 & .846 \\
\hline
\end{tabular}

\section{ANALYSIS AND INTERPRETATION}

In the above table the $\mathrm{p}$ value is $>0.05$ so that the null hypothesis is accepted. THERE IS NO SIGNIFICANT DIFFERENCE BETWEEN CROP LOAN AND INCOME PER CULTIVATION 


\section{HYPOTHESIS-C}

HO- THERE IS NO SIGNIFICANT DIFFRENCE BETWEEN CROP LOAN AND INCOME PER CULTIAVTION

H1- THERE IS A SIGNIFICANT DIFFERENCE BETWEEN CROP LOAN AND INCOME PER CULTIVATION

\section{CROP NAME- TOMATO}

Paired Samples Statistics

\begin{tabular}{|c|c|c|c|c|c|}
\hline \multicolumn{2}{|c|}{} & Mean & N & Std. Deviation & $\begin{array}{c}\text { Std. Error } \\
\text { Mean }\end{array}$ \\
\hline \multirow{2}{*}{ Pair 1 } & BEFORE & 27522.7273 & 11 & 16756.15355 & 5052.17039 \\
\cline { 2 - 6 } & AFTER & 27863.6364 & 11 & 15612.64057 & 4707.38825 \\
\hline
\end{tabular}

Paired Samples Correlations

\begin{tabular}{|c|c|c|c|c|}
\hline \multicolumn{2}{|c|}{} & N & Correlation & Sig. \\
\hline Pair 1 & $\begin{array}{c}\text { BEFORE \& } \\
\text { AFTER }\end{array}$ & 11 & .950 & .000 \\
\hline
\end{tabular}

Paired Samples Test

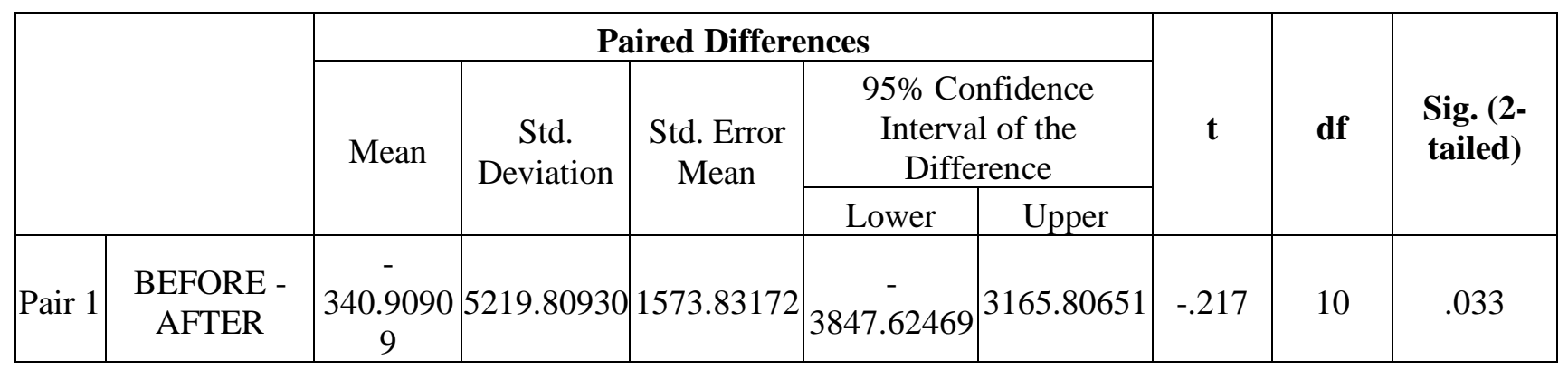

\section{ANALYSIS AND INTERPRETATION-}

In the above table the $\mathrm{P}$ value is Less than the 0.05 so, that Alternative Hypothesis $(\mathrm{H} 1)$ is accepted.

\section{THERE IS A SIGNIFICANT DIFFERNCE BETWEEN CROP LOAN AND INCOME PER CULTIVATION}

\section{HYPOTHESIS-C}

HO - THERE IS NO SIGNIFICANT DIFFRENCE BETWEEN CROP LOAN AND INCOME PER CULTIVATION

H1- THERE IS A SIGNIFICANT DIFFERENCE BETWEEN CROP LOAN AND INCOME PER CULTIVATION

\section{CROP NAME-RAGI}

Paired Samples Correlations

\begin{tabular}{|l|l|c|c|c|}
\hline \multicolumn{2}{|l|}{} & $\mathbf{N}$ & Correlation & Sig. \\
\hline Pair 1 & BEFORE \& AFTER & 30 & .893 & .000 \\
\hline
\end{tabular}


A Study on Impact of Crop Loan to the Agriculture Development with Special to Refrence Co-

Operative Agriculture and Rural Development Bank

Paired Samples Test

\begin{tabular}{|c|c|c|c|c|c|c|c|c|c|}
\hline & \multicolumn{5}{|c|}{ Paired Differences } & \multirow{3}{*}{$\mathbf{t}$} & \multirow{3}{*}{ df } & \multirow{3}{*}{$\begin{array}{l}\text { Sig. (2- } \\
\text { tailed) }\end{array}$} \\
\hline & & \multirow{2}{*}{ Mean } & \multirow{2}{*}{$\begin{array}{c}\text { Std. } \\
\text { Deviation }\end{array}$} & \multirow{2}{*}{\begin{tabular}{|c|} 
Std. Error \\
Mean
\end{tabular}} & \multicolumn{2}{|c|}{\begin{tabular}{|c|}
$95 \%$ Confidence Interval \\
of the Difference
\end{tabular}} & & & \\
\hline & & & & & \begin{tabular}{|l|} 
Lower \\
\end{tabular} & Upper & & & \\
\hline Pair 1 & $\begin{array}{l}\text { BEFORE - } \\
\text { AFTER }\end{array}$ & 1033.06667 & 3480.36553 & 635.42490 & -266.52318 & 2332.65651 & 1.626 & 29 & .115 \\
\hline
\end{tabular}

Paired Samples Statistics

\begin{tabular}{|c|c|c|c|c|c|}
\hline \multicolumn{2}{|c|}{} & Mean & N & Std. Deviation & Std. Error Mean \\
\hline \multirow{2}{*}{ Pair 1 } & BEFORE & 22383.0667 & 30 & 7479.97783 & 1365.65086 \\
\cline { 2 - 6 } & AFTER & 21350.0000 & 30 & 7561.41521 & 1380.51923 \\
\hline
\end{tabular}

\section{ANALYSIS AND INTERPRETATION-}

In the above table the P value is Greater than the 0.05 , so that the Null hypothesis is accepted.

\section{CONCLUSSION}

THERE IS NO SIGNIFICANT DIFFERNCE BETWEEN CROP LOAN AND INCOME PER CULTIVATION

\section{HYPOTHESIS-C}

HO- THERE IS NO SIGNIFICANT DIFFERENCE BETWEEN CROP LOAN AND INCOME PER CULTIVATION

H1- THERE IS A SIGNIFICANT DIFFERENCE BETWEEN CROP LOAN AND INCOME PER CULTIVATION

\section{CROP NAME- CRON}

Paired Samples Statistics

\begin{tabular}{|l|l|l|l|l|l|}
\hline \multicolumn{2}{|c|}{} & Mean & N & Std. Deviation & $\begin{array}{l}\text { Std. Error } \\
\text { Mean }\end{array}$ \\
\hline \multirow{2}{*}{ Pair 1 } & BEFORE & 17671.5152 & 33 & 4104.96051 & 714.58190 \\
\cline { 2 - 6 } & AFTER & 16706.0606 & 33 & 4386.62309 & 763.61306 \\
\hline
\end{tabular}

Paired Samples Correlations

\begin{tabular}{|l|l|c|c|c|}
\hline \multicolumn{2}{|l|}{} & $\mathbf{N}$ & Correlation & Sig. \\
\hline Pair 1 & BEFORE \& AFTER & 33 & .771 & .000 \\
\hline
\end{tabular}

Paired Samples Test

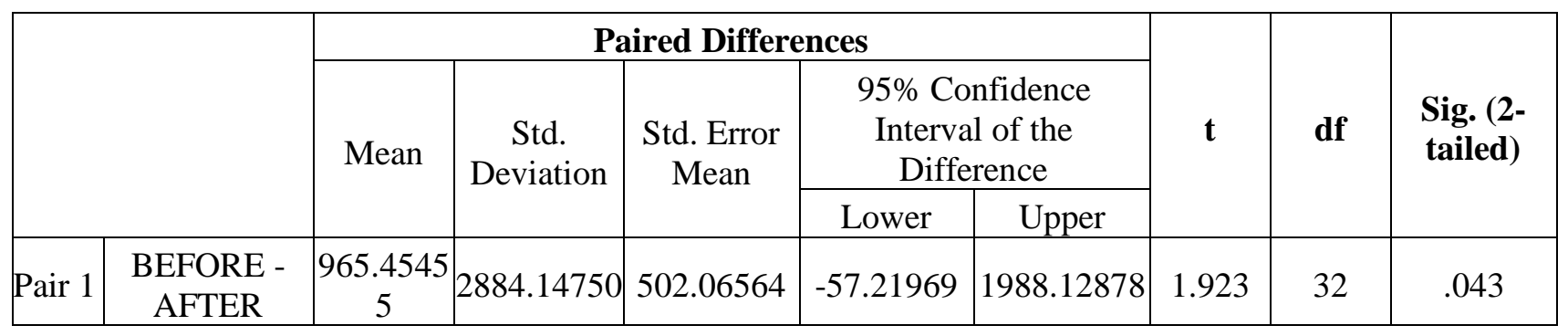




\section{ANALYSIS AND INTERPRETATION-}

In the above table the $\mathrm{p}$ value is Less than the 0.05 so that the Alternative Hypothesis accepted.

\section{CONCLUSSION-}

THERE IS A SIGNIFICANT DIFERENCE BETWEEN CROP LOAN AND INCOME PER CULTIVATION

\section{HYPOTHESIS-D}

HO - THERE IS NO SIGNIFICANCE DIFFRENCE BETWEEN CROP LOAN AND LIABILITIES

H1- THERE IS A SIGNIFICANT DIFFERENCE BETWEEN CROP LOAN AND LIABILITIES

\section{LOAN FROM BANKS}

Paired Samples Statistics

\begin{tabular}{|c|c|c|c|c|c|}
\hline \multicolumn{2}{|c|}{} & Mean & N & Std. Deviation & $\begin{array}{c}\text { Std. Error } \\
\text { Mean }\end{array}$ \\
\hline \multirow{2}{*}{ Pair 1 } & BEFORE & 191177.5000 & 40 & 213052.04070 & 33686.48544 \\
\cline { 2 - 6 } & AFTER & 156250.0000 & 40 & 167080.01308 & 26417.66964 \\
\hline
\end{tabular}

Paired Samples Correlations

\begin{tabular}{|l|c|c|c|c|}
\hline \multicolumn{2}{|l|}{} & N & Correlation & Sig. \\
\hline Pair 1 & BEFORE \& AFTER & 40 & .952 & .000 \\
\hline
\end{tabular}

Paired Samples Test

\begin{tabular}{|c|c|c|c|c|c|c|c|}
\hline & \multicolumn{4}{|c|}{ Paired Differences } & \multirow{3}{*}{$\mathbf{t}$} & \multirow{3}{*}{ df } & \multirow{3}{*}{$\begin{array}{l}\text { Sig. (2- } \\
\text { tailed) }\end{array}$} \\
\hline & \multirow[t]{2}{*}{ Mean } & \multirow[t]{2}{*}{$\mid \begin{array}{l}\text { Std. } \\
\text { Deviation }\end{array}$} & \multirow[t]{2}{*}{$\begin{array}{l}\text { Std. Error } \\
\text { Mean }\end{array}$} & $\begin{array}{l}95 \% \text { Confidence } \\
\text { Interval of the } \\
\text { Difference }\end{array}$ & & & \\
\hline & & & & \begin{tabular}{|l|l|} 
Lower & Upper \\
\end{tabular} & & & \\
\hline \begin{tabular}{l|l} 
Pair 1 & $\begin{array}{l}\text { BEFORE - } \\
\text { AFTER }\end{array}$
\end{tabular} & $\begin{array}{l}34927.500 \\
00\end{array}$ & $\begin{array}{l}74481.792 \\
60\end{array}$ & $\begin{array}{l}11776.605 \\
4\end{array}$ & 4 \begin{tabular}{l|l}
11107.0671 & 58747.9329 \\
0 & 0
\end{tabular} & 2.966 & 39 & .005 \\
\hline
\end{tabular}

\section{ANALYSIS AND INTERPRETATION-}

In the above table the $\mathrm{P}$ value is less than the 0.05 so that the Alternative Hypothesis is Accepted.

THERE IS A SIGNIFICANT DIFFRENCE BETWEEN CROP LOAN AND LIABILITIES

\section{HYPOTHESIS -D}

HO - THERE IS NO SIGNIFICANT DIFFRENCE BETWEEN CROP LOAN AND LIABILITIES

H1- THERE IS A SIGNIFICANT DIFFERENCE BETWEEN CROP LOAN AND LIABILITIES 
A Study on Impact of Crop Loan to the Agriculture Development with Special to Refrence Co-

Operative Agriculture and Rural Development Bank

\section{AGRICULTURE JEWEL LOAN}

Paired Samples Statistics

\begin{tabular}{|c|c|c|c|c|c|}
\hline \multicolumn{2}{|c|}{} & Mean & N & Std. Deviation & $\begin{array}{c}\text { Std. Error } \\
\text { Mean }\end{array}$ \\
\hline \multirow{2}{*}{ Pair 1 } & BEFORE & 89370.0000 & 40 & 132819.48652 & 21000.60475 \\
\cline { 2 - 6 } & AFTER & 71825.0000 & 40 & 86720.56140 & 13711.72470 \\
\hline
\end{tabular}

Paired Samples Correlations

\begin{tabular}{|l|c|c|c|c|}
\hline \multicolumn{2}{|c|}{} & N & Correlation & Sig. \\
\hline Pair 1 & $\begin{array}{c}\text { BEFORE \& } \\
\text { AFTER }\end{array}$ & 40 & .984 & .000 \\
\hline
\end{tabular}

Paired Samples Test

\begin{tabular}{|c|c|c|c|c|c|c|c|c|c|}
\hline & & \multicolumn{5}{|c|}{ Paired Differences } & \multirow[t]{3}{*}{$\mathbf{t}$} & \multirow[t]{3}{*}{ df } & \multirow{3}{*}{$\begin{array}{l}\text { Sig. (2- } \\
\text { tailed) }\end{array}$} \\
\hline & & \multirow[t]{2}{*}{ Mean } & \multirow[t]{2}{*}{$\begin{array}{c}\text { Std. } \\
\text { Deviation }\end{array}$} & \multirow[t]{2}{*}{$\begin{array}{l}\text { Std. Error } \\
\text { Mean }\end{array}$} & \multicolumn{2}{|c|}{$\begin{array}{c}95 \% \text { Confidence Interval } \\
\text { of the Difference }\end{array}$} & & & \\
\hline & & & & & \begin{tabular}{|l|} 
Lower \\
\end{tabular} & Upper & & & \\
\hline Pair 1 & $\begin{array}{l}\text { BEFORE - } \\
\text { AFTER }\end{array}$ & $\begin{array}{c}17545.000 \\
00\end{array}$ & $\begin{array}{c}49991.3887 \\
5\end{array}$ & 7904.33259 & 1556.97824 & $\begin{array}{c}33533.0217 \\
6\end{array}$ & 2.220 & 39 & .032 \\
\hline
\end{tabular}

\section{ANALYSIS AND INTERPRETATION-}

In the above table the $\mathrm{P}$ value is less than 0.05 , so that the alternative Hypothesis $(\mathrm{H} 1)$ is accepted.

\section{CONCLUSSION-}

THERE IS A SIGNIFICANCE DIFFRENCE BETWEEN CROP LOAN AND LIABILITIES

\section{HYPOTHESIS-D}

HO - THERE IS NO SIGNIFICANCE DIFFRENCE BETWEEN CROP LOAN AND LIABILITIES.

H1- THERE IS A SIGNIFICANT DIFFERENCE BETWEEN CROP LOAN AND LIBILITIES

\section{LAND TAX}

Paired Samples Statistics

\begin{tabular}{|c|c|c|c|c|c|}
\hline \multicolumn{2}{|c|}{} & Mean & N & Std. Deviation & $\begin{array}{c}\text { Std. Error } \\
\text { Mean }\end{array}$ \\
\hline \multirow{2}{*}{ Pair 1 1 } & BEFORE & 28900.0000 & 10 & 19664.97168 & 6218.61006 \\
\cline { 2 - 6 } & AFTER & 22700.0000 & 10 & 16268.92061 & 5144.68442 \\
\hline
\end{tabular}

Paired Samples Correlations

\begin{tabular}{|l|l|c|c|c|}
\hline \multicolumn{2}{|l|}{} & N & Correlation & Sig. \\
\hline Pair 1 & BEFORE \& AFTER & 10 & .986 & .000 \\
\hline
\end{tabular}


Paired Samples Test

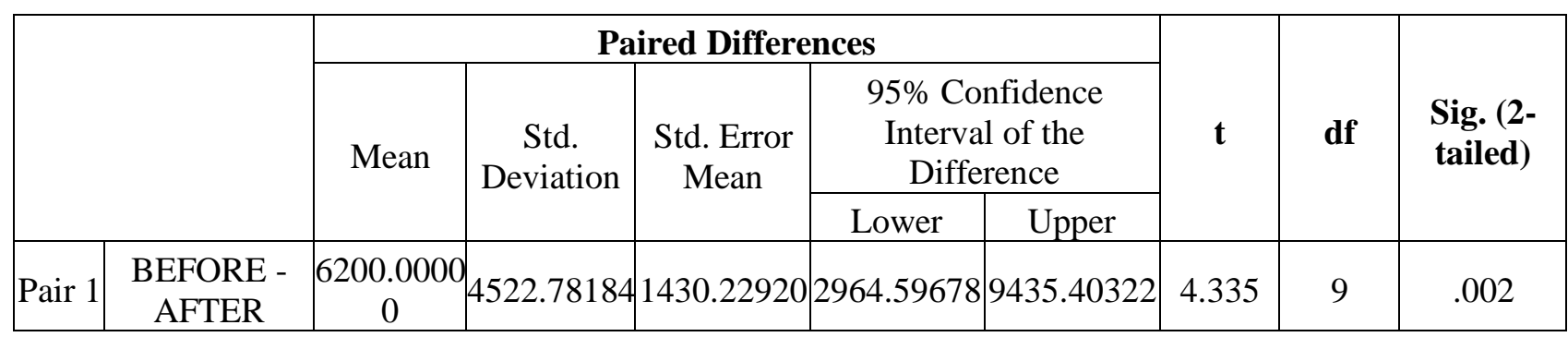

ANALYSIS AND INTERPRETATION-

In the above table the p value is less than 0.05 so, that the alternative hypothesis (H1) is accepted

CONCLUSSION-

THERE IS A SIGNIFICANCE DIFFRENCE BETWEEN CROP LOAN AND LIABAILITIES.

HYPOTHESIS-D

\section{Ho - THERE IS NO SIGNIFICANT DIFFRENCE BETWEEN CROP LOAN AND LIABLITIES \\ H1- THERE IS A SIGNIFICANT DIFFERENCE BETWEEN CROP LOAN AND LIBLITIES.}

\section{LOAN FROM OTHERS}

Paired Samples Statistics

\begin{tabular}{|c|c|c|c|c|c|}
\hline \multicolumn{2}{|c|}{} & Mean & N & Std. Deviation & Std. Error Mean \\
\hline \multirow{2}{*}{ Pair 1 } & BEFORE & 13850.0000 & 10 & 6984.30781 & 2208.63206 \\
\cline { 2 - 6 } & AFTER & 12850.0000 & 10 & 5207.09985 & 1646.62955 \\
\hline
\end{tabular}

Paired Samples Correlations

\begin{tabular}{|c|c|c|c|c|}
\hline \multicolumn{2}{|c|}{} & $\mathrm{N}$ & Correlation & Sig. \\
\hline Pair 1 & $\begin{array}{c}\text { BEFORE \& } \\
\text { AFTER }\end{array}$ & 10 & .884 & .001 \\
\hline
\end{tabular}

Paired Samples Test

\begin{tabular}{|c|c|c|c|c|c|c|c|c|c|}
\hline & \multicolumn{5}{|c|}{ Paired Differences } & \multirow{3}{*}{$\mathrm{t}$} & \multirow{3}{*}{$\mathrm{df}$} & \multirow{3}{*}{$\begin{array}{l}\text { Sig. (2- } \\
\text { tailed) }\end{array}$} \\
\hline & & \multirow[t]{2}{*}{ Mean } & \multirow[t]{2}{*}{$\begin{array}{c}\text { Std. } \\
\text { Deviation }\end{array}$} & \multirow[t]{2}{*}{$\begin{array}{l}\text { Std. Error } \\
\text { Mean }\end{array}$} & \multicolumn{2}{|c|}{$\begin{array}{l}95 \% \text { Confidence } \\
\text { Interval of the } \\
\text { Difference }\end{array}$} & & & \\
\hline & & & & & Lower & Upper & & & \\
\hline Pair 1 & $\begin{array}{c}\text { BEFORE - } \\
\text { AFTER }\end{array}$ & $\begin{array}{c}6200.0000 \\
0\end{array}$ & 4522.78184 & 1430.22920 & 2964.59678 & 9435.40322 & 4.335 & 9 & .002 \\
\hline
\end{tabular}

\section{ANALYSIS AND INTERPRETATION-}

In this above table the $\mathrm{P}$ value is less than the 0.05 so, that the alternative hypothesis $(\mathrm{H} 1)$ is accepted. 
A Study on Impact of Crop Loan to the Agriculture Development with Special to Refrence Co-

Operative Agriculture and Rural Development Bank

THERE IS A SIGNIFICANT DIFFRENCE BETWEEN CROP LOAN AND

LIABILITIES

HYPOTHESIS RESULTS-

HYPOTHESIS-A

H0-THERE IS NO SIGNIFICANT DIFFRENCE BETWEEN CROP LOAN AND AREA OF CULTIVATION

\begin{tabular}{|c|c|c|c|c|}
\hline SL.NO & CROP NAME & RESPONDENTS & P VALUE & RESULT \\
\hline 1 & PADDY & 17 & 0.011 & REJECTED \\
\hline 2 & BANANA & 9 & 0.041 & REJECTED \\
\hline 3 & TOMATO & 11 & 0.517 & ACCEPTED \\
\hline 4 & RAGI & 30 & 0.01 & REJECTED \\
\hline 5 & CRON & 33 & 0.534 & ACCEPTED \\
\hline & TOTAL & 100 & & \\
\hline
\end{tabular}

\section{HYPOTHESIS-B}

H0- THERE IS NO SIGNIFICANT DIFFERENCE BETWEEN CROP LOAN AND EXPENDITURE PER CULTIVATION

\begin{tabular}{|c|c|c|c|c|}
\hline SL.NO & CROP NAME & RESPONDENTS & P VALUE & RESULTS \\
\hline 1 & PADDY & 17 & 0.008 & REJECTED \\
\hline 2 & BANANA & 9 & 0.028 & REJECTED \\
\hline 3 & TOMATO & 11 & 0.512 & ACCEPTED \\
\hline 4 & RAGI & 30 & 0.069 & REJECTED \\
\hline 5 & CRON & 33 & 0.045 & REJECTED \\
\hline
\end{tabular}

\section{HYPOTHESIS- C}

HO-THERE IS NO SIGNIFICANT DIFFERENCE BETWEEN CROP LOAN AND INCOME PER CULTIVATION

\begin{tabular}{|c|c|c|c|c|}
\hline SL.NO & CROP LOAN & RESPONDENTS & P VALUE & RESULTS \\
\hline 1 & PADDY & 17 & 0.042 & REJECTED \\
\hline 2 & BANANA & 9 & 0.846 & ACCEPTED \\
\hline 3 & TOMATO & 11 & 0.032 & REJECTED \\
\hline 4 & RAGI & 30 & 0.115 & ACCEPTED \\
\hline 5 & CRON & 33 & 0.043 & REJECTED \\
\hline
\end{tabular}

\section{HYPOTHESIS- D}

H0-THERE IS NO SIGNIFICANT DIFFRENCE BETWEEN CROP LOAN AND LIABILITIES

\begin{tabular}{|c|c|c|c|c|}
\hline SL.NO & LIABILITIES & RESPONDENTS & P VALUE & RESULT \\
\hline 1 & LOANS FROM BANKS & 40 & 0.005 & REJECTED \\
\hline 2 & AGRICULTURE JEWEL LOAN & 40 & 0.032 & REJECTED \\
\hline 3 & LANDTAX & 10 & 0.002 & REJECTED \\
\hline 4 & LOAN FROM OTHERS & 10 & 0.002 & REJECTED \\
\hline
\end{tabular}

*The $\mathrm{P}$ value is less than 0.05-Alternative Hypothesis (H1) is Accepted, the P value is Greater than 0.05 the Null Hypothesis is Accepted (H0). 


\section{FINDINGS, SUGGESTIONS AND CONCLUSSION}

\subsection{Findings}

- In the study of 100 respondents the major the respondents borrowed loan amount more than 20000(32\%), the respondents prefer to borrowed high amount, and other respondents is $22 \%$ is borrowed below 5000 .

- The age of respondents is 30-40 is highly borrowed the amount of loan (29\%), and above 50 to 60 are respondents is borrowed small amount loans $(21 \%)$.

- In the study of genders, the males $72 \%$ are borrowed loans and females are $28 \%$, so that the males are borrowed high when compare to the females.

- The religions the Hindu are borrowed $48 \%$, and the Christiane is $25 \%$, and Muslim is $27 \%$ is borrowed loans.

- In the community basis $45 \%$ of OBC, $40 \%$ GM are borrowed loans and SC, ST Is $10 \%$ and $5 \%$.

- In the study of the qualification of the respondents of loan borrowers $35 \%$ are uneducated is high when compare to others. And second is graduates were $29 \%$.

- In the study of the occupation of the borrowers the farmers are high (70\%) to loans.

- In the number of dependents of respondents above 4 is borrowed $37 \%$ and 3-4 is $36 \%$.

- Nature of house by the respondents is thatched is $42 \%$ and concrete is $27 \%$ and the ownership of house is $84 \%$ owned.

- Annual income of the respondents is being the $44 \%$ of the people is to above 60000 . The ownership of land $-78 \%$.

- Size of land of holding semi medium farmers $40 \%$, marginal farmers-32\%.

- Sources of irrigation is to rain fall and pump sets-30\%, purpose of borrowings loan is corn cultivation $33 \%$, and ragi cultivation- $30 \%$.

- The study of problems regarding the crop cultivation is the monsoon failure (35\%) and financial shortage (30\%).

- The reasons for availing of crop loan is to less time consuming and government subsidiaries.

- In the sources of finance interest from the respondents is to co-operative societies, and land development banks.

- The reasons for overdues of the respondents is to the crop failures and low yield returns. And the reasons for irregular of payments to monsoon failure.

- The problems of crop loan from the primary agriculture co-operative and rural development banks is to lending policies and procedures, delay in sanctioning of loan, and societies follows more formalities.

- In the study the impact of crop loan to the agriculture development the following finding were find by the analysis.

- Impact on crop loan to the area of cultivation

- In this study paddy impact on area of cultivation, banana is also impacted, tomato not impacted, ragi impacted, and corn not impacted.

- Impact on crop loan to the production per acre Paddy- impacted, Banana- not impacted, Tomato-impacted, Ragi- not impacted, Corn- impacted. 
A Study on Impact of Crop Loan to the Agriculture Development with Special to Refrence Co-

Operative Agriculture and Rural Development Bank

- Impact on crop loan to the Expenditure, Paddy- impacted, Banana-impacted, Tomatonot impacted, Ragi-not impacted, Corn-impacted.

- Impact on crop loan to the Income, Paddy- impacted, Banana- not impacted, Tomatoimpacted, Ragi- not impacted, Corn-impacted.

- The crop loan impact the savings pattern of the loan borrowers and income of the borrowers, assets and liabilities of the crop loan borrower.

\subsection{SUGGESTIONS}

On the basis of the Above Findings the following Suggestions are made to improve the crop loans and borrowers living standards.

\subsubsection{Suggestions for the government}

- To increasing the agriculture production the government should take necessary actions to suppling of water, right seeds, fertilizers, technologies, for the farmers.

- According to the study in primary co-operative and rural development banks the formalities is granting the loan is problems for the customers. The government will reduce the formalities.

- The government take actions for reducing of selling of agriculture lands.

- The farmers or borrowers of crop loan followed the traditional cultivation methods for cultivation the government should aware them.

- The government should regulate the market price for all agriculture products.

- The government is implementing the various schemes and make them to successful.

\subsubsection{Suggestions to the Primary Co-operative Agriculture and Rural Development Banks}

- The banks are encouraging the farmers to increasing the production of crops.

- The PAC and RD banks should input the new technologies in banking activities the delay of banking activities may be reduced.

- The loan recovery is improved by the banks.

- The PACRD s help for the members to maintain the books of accounts of their cultivations.

\subsubsection{Suggestions to the crop loan borrowers}

- The crop loan borrower should repay the loan amount correctly.

- The crop insurance made by the farmers of their crops and make protect the crops.

- The crop loan borrowers should be adapting the new technologies or modern methods for cultivation and make the increasing in the crop production.

- The crop loan borrower should be use for crop cultivation did not use the loan amount for other purpose.

- The farmers stop to lending the money form the money lenders and Pawan brokers.

\section{CONCLUSSION}

The study of the project is to be the IMPACT OF CROP LOAN TO THE AGRICULTURE DEVELOPMENT WITH SPECIAL REFERENCE PRIMARY CO-OPERATIVE AGRICULTURE AND RURAL DEVELOPMENT BANK. 
This study has been undertaken mainly to help the government to take up policy decisions and formulate suitable schemes and programmed to the agriculture formers. The study gives comprehensive ideas of the various problems which are the primary agricultural cooperative and rural development bank face and effective implementation of schemes introduced by the governments for the formers. The suggestion made in the study will support to solving in the problems of the crop cultivators and primary agricultural cooperative and rural development bank.

The study mainly focusses on to gives crop loans for utilizing the formers and its impact on agriculture pre-loan and post-loan. This helps to the formers to developing the crop activities and its develops crop loans schemes.

In the study the analysis has been made as per the results of the t-test using in the data analysis. The impact is considered the results of the statistical tools.

The study will make the overall crop loan borrowers of the PCA and RD banks, and problems for the Crop loan schemes and the finally impact on the crop loan to the area of cultivation, production per acre, and expenditure and income, assets and liablities, income analysis and savings pattern of the crop loan borrowers.

In the study will made by the respondents and responses.

So, that the study is concluded that the crop loan is impacted by the agriculture activities. The government has to make the crop loan schemes effectively.

\section{BIBILOGRAPHY}

\section{Books}

- Co-operative management - (optional) Bangalore university.

- Srivastava, R.B- "Crop loan of Agriculture in India", Vohra publishers and distributors Allahabad, 2004-July.

\section{Reports-}

- Chikkaballpurdistrct financial reports.

- Financial reports of the bank.

- Karnataka state agriculture reports.

\section{Review of literature References}

[1] Amuthasuraibi J, and Vasanth Kumar - "Sustainable Agriculture Development", Kian world January 2001.

[2] Arunthse and Zeaden - "A Study on villanur block Region - Financing Agriculture", July 2000.

[3] Bhai and Ganeshwar- "A Study Co-operatives crop loan overdue", 1997.

[4] Chandrashekar S, Manika S, and Soleman Raj D- "Role of Agriculture in cultivator generation", Southern economists, 2011.

[5] Geetha K- "Impact on crop loan to the Agriculture Development - Kanyakumari District", 2012

[6] Ishwara S C, Dhigra- "The Indian Economy Environment and Policy", Sulthan Chand and sons, Mumbai ,2010.

[7] Nidhesh K B- "Role of Co-operative Banks into the credit needs of Rural masses", Kisan World, 2009. 
A Study on Impact of Crop Loan to the Agriculture Development with Special to Refrence CoOperative Agriculture and Rural Development Bank

[8] Saraiya S G- "Rural banking In India", 1998.

[9] Srivasthava B - "Crop loan of Agriculture in India", 2004.

[10] VincelyJabakar - "Impact of Institutions credit on Agricultural development, Ph.D. Thesis, ManomamiunSundarar University, Tiruvelnali.

\section{Websites: -}

- www.agricultureinchikkaballapur.com

- www.co-operativebanks.com

- www.primaryagriculturco-operativebanks.com

- www.agricultureinindia.com 